\title{
VIDÉKFEJLESZTÉS A FEJLŐDÉSELMÉLETEK ÉS A FEJLESZTÉSI KONCEPCIÓK TÜKRÉBEN ${ }^{1}$
}

\section{(Rural Development in Scope of the Development Theories and Concepts)}

\author{
FARKAS TIBOR
}

Kulcsszavak:

fejlödés vidékfejlesztés terïletfejlesztés agrárfejlesztés

Az alábbi dolgozat a fejlödéssel és a fejlesztéssel kapcsolatos fogalmakat és koncepciókat veszi sorra. Azért tartjuk fontosnak ezeknek a fogalmaknak a tisztázását, hogy a fejlesżések célját könnyebben meg tudjuk határozni. Ha nem tudjuk ugyanis, hogy a fejlesztések milyen változásokat okoznak, ill. azt, hogy milyen változást szeretnénk mi magunk elérni, nem szabad fejlesztési tevékenységbe kezdeni. A cikk több vitatott fogalmat is értelmez, külön kiemelve a vidékfejlesztést és a hozzá kapcsolódó megközelítéseket.

A vidékfejlesztés egyre gyakrabban, ám sok esetben felületesen kezelt és használt kifejezés. Különbơző megfontolások alapján Európán kívül, az Európai Unióban és Magyarországon is az érdeklödés homlokterébe került, s ennek egyik legfontosabb oka az, hogy a vidéki területek funkciói megváltoztak. A vidék ma már nem kizárólag csak az élelemtermelés színhelye, hanem a tájkép, a környezet megóvásának és fenntartásának, az alternatív foglalkoztatási lehetôségeknek a tere és egyben posztmodern élvezeti cikk is. Mindazonáltal a vidék fontossága fỏként csak a szlogenek szintjén érzékelhető. Az igazi erővonalak továbbra is a piac- és profitorientált, környezeti, táji és kulturális hagyományokat kevésbé figyelembe vevó erỏvonalak mentén húzódnak. A vidékfejlesztés ezért sok esetben csak fejlesztési alternativaként jelentkezik, különösen az elmaradottabb és „vidékibb” (kis)térségek számára. Elöször azokat a fogalmakat és elméleteket vesszük sorra, amelyek szorosabban kapcsolódnak a fejlődés problémaköréhez. A továbbiakban a vidékfejlesztés helyét próbáljuk meghatározni a területfejlesztés, az agrárfejlesztés valamint az egyéb fejlesztési koncepciók kömyezetében.

\section{A fejlödés értelmezése}

\section{A fejlödésröl általában}

Mielőtt bárki fejlesztésbe kezdene, el kellene gondolkodnia azon, hogy vajon munkája fejlődést fog-e eredményezni. (A fejlesztést úgy is definiálhatjuk, hogy az a tevékenység, amely fejlödést eredményez.) A fejlődés fogalmát mindenekelött meg kell különböztetnünk a változás fogalmától. A fejlődés - szemben a văltozással szándékos, emberek által végrehajtott, nem véletlenszerü folyamatnak az eredménye, amely több dimenzió mentén, többféle szereplóvel és különbözỏ területi szinteken történik. ${ }^{2}$ 
Egy filozófiai szempontú elemzés szerint a fejlódés nem szükségszerủen hasznos folyamat. Szakolczai (1990) nem állítja, hogy soha és semmiben nem létezik fejlödés, és azt sem, hogy oktalanság a dolgok jobbrafordulásában reménykedni. Azt sem mondja, hogy a hatalmat teljesen ki lehet, ill. ki kell-e egyáltalán küszöbölni az emberi együttélésböl, viszont úgy gondolja, hogy a különbözö fejlödéselméletek a hatalmi mechanizmusok hátterei és mozgatórugói. Segítségükkel a hatalom gyakorlói megszabják az egyes emberek cselekvési lehetőségeit, a fejlődésre való hivatkozással jogossá teszik és eltakarják a nevében alkalmazott hatalmat. „A korlátozott, leszủkített területen való örökös előrehaladás kérdéses ígéretének felhasználásával egy hatalmi tevékenység kíván ugyanis a szükségböl erényt kovácsolni, az embereket saját világuk értékeinek felszámolására rávenni, saját lehetőségeik becsatornázására mozgósítani. Létrejön az az eltolódás, melynek eredményeként az egyes területeken bekövetkezett fejlödés más területeken folytatott hatalmi tevékenység igazolására vagy eltakarására szolgál." (Szakolczai 1990, 10)

Az anarchisták egyenesen kétségbe vonják magát a fejlődés tényét. Szerintük (Walter 1994) a történelem például nem egy folyamatos vagy dialektikus fejlödési vonal, hanem dualisztikus folyamat. Az emberiség - állítják - ma egyik irányba halad, holnap egy másikba. Egy rendszer felemelkedése vagy egy régi bukása nem jelent sem titokzatos törést a fejlödésben, sem egy különleges fejlödési szakaszt. Mások is szkeptikusak a fogalommal kapcsolatban: ,... a fejlődés fogalma alig több, mint egy lusta gondolkodónak mindent megfogni akaró meghatározása, ami mindent átfogna a széles, meghatározatlan változásokból a meglehetősen specifikus események közül. Mint információközlö, a fogalom gyakorlatilag haszontalan." (Welch 1984 - idézi Hoggart-Buller 1994) A fejlödés tényét azonban a legtöbben elfogadjuk. A legalapvetőbb szinten a fejlődés egy olyan normatív koncepció lehet, ami elöremozdulást jelent. Goulet (1971 - idézi Hoggart-Buller 1994) szerint a változások teljes skáláját lefedi, és egy bizonyos rendszer elemeinek olyan elmozdulását jelenti, amely a nem kielégító életfeltételektől az emberileg jobbnak tartott életfeltételek megvalósulásáig tart.

Rendszerelméleti szempontból a fejlődés szerkezeti változást jelent. A fejlödés időbeli dinamikája annál nagyobb, minél nagyobb szerkezeti változások következnek be. Kedvezötlen irányú szerkezeti változás esetén a rendszer visszafejlödik. A rendszer fejlódési lehetőségeit alapvetően meghatározza integráltsági foka, amely az előzőleg végbement integrációs és dezintegrációs folyamatok eredménye. Az integráció maga olyan folyamatot jelent, amelynek során növekszik a rendszer elemei közötti kapcsolatok, összefüggések, kölcsönhatások száma, intenzitása, s ezáltal fokozódik a rendszer strukturáltsága, szervezettsége, sokoldalúsága. Minél integráltabb egy rendszer, annál hatékonyabban müködik, a gazdasági-társadalmi jellegủ rendszerek esetén annál alacsonyabb a fenntartás, azaz a menedzsment költsége, ugyanakkor a szerkezet/szervezet rugalmassága annál kisebb, vagyis annál kevésbé alkalmas fejlődésre.

$\mathrm{Az}$ erősen integrált rendszereket az egyensúlyhiány olyan nagyfokú szerkezetváltozásra késztetheti, hogy az a szervezetnek a szétesésével, megszünésével is 
Farkas Tibor : Vidékfejlesztés a fejlödéselméletek és a fejlesztési koncepciók tükrében Tér és Társadalom 16. évf. 2002/1. 41-57. p.

járhat. Az egyensúlyhiány másik megjelenési formája a sokféleség vagy a sokoldalúság lehet. A ,fiatal” vagy tanuló rendszerekre jellemző ez a sokoldalúság, amely biztosítja a fejlődéshez szükséges információt. Ứj információ hiányában ugyanis a rendszer leáll. Csak akkor termelődnek újabb információk, ha megörzi sokféleségét. Amennyiben a rendszerben megszünik a sokféleség, olyan egyensúlyi helyzet alakulhat ki, amely hosszú stagnálásra itélhet akár egy régiót vagy egész országokat is. Ezt a sajátos döntési helyzetet fejlődési csapdának tekinthetjük. Minél magasabb fejlettségi szinten alakul ki ilyen fejlődési csapda, annál hosszabb ideig tart a stagnálás (és annál veszélyesebb a rendszer egészére nézve) (Szakál 1998).

Fejlődés anélkül is létezik, hogy az emberek (a kutatók, a fejlesztők, a politikusok) beavatkoznának a változásokba. A rendszerek, közösségek bizonyos folyamatokon mennek keresztül, vagy bizonyos változásokat szenvednek el. Ha pozitív irányba történik a változás, akkor azt fejlỏdésnek, ha számukra nem kívánatos irányba történik a változás, akkor leromlásnak, esetleg degradálódásnak nevezhetjük. A fejlesztésnek olyan tudatos beavatkozásnak kell lennie, amelynek a végsö célja és eredménye fejlődés lesz (Cernea 1994).

A fejlődés értelmezése azonban az adott gazdasági, politikai és ideológiai viszonyoktól is függ, de az egyes ágazati szempontok is befolyásolják. Hogy aktuálisan mi a fejlődés, az személyes értékelés tárgya. Annyi bizonyos, hogy nem egyformán értékeljük a változásokat. A McDonald's gyorsétkeztetés elterjedése vagy a motorizáció pl. nem mindenki számára jelent fejlődést. Egyetlen ember vagy közösség értékítéletén tehát semmiképpen nem alapulhat a fejlődés megítélése. Nagy eltérések adódhatnak a különböző társadalmakon belül is. A nyugati társadalmakban pl. erős az individualizmus eszménye, míg az ázsiai országokban az egyén kevésbé fontos szerepet tölt be, a hangsúly a közösségen van.

A közgazdaságtanban fejlődésen általában gazdasági fejlődést értünk. A gazdasági fejlődés pedig nem jelent mást, mint az egy főre jutó GDP növekedése mellett a gazdasági szerkezet átalakulását és a gazdálkodás hatékonyságának emelkedését. A modern gazdaság fejlődésének egyik legfontosabb tényezöje a piac. A piac azonban viszonylag új jelenség az emberiség történetében. Többek között Polányi (1997) is foglalkozott a modern gazdaság és piac jelentőségével. 1946-ban megjelent mủvében a gazdaság és a piac mindenhatóságába vetett hit kialakulásáról is ír. Mủvében kiemeli, hogy a társadalom nem csak a piac közremúködésével tud müködni. A hagyományos társadalmakban a társadalom müködését a redisztribúció és a reciprocitás biztosítja. Az anyagi javak birtoklása helyett fontosabb ezekben a közösségekben a társadalmi állás (státusz) és a közösségi érdek. A termelési eszközök gyors fejlődése, a gazdasági fejlödés a társadalomnak a szétzilálódásához vezet, ezért a piac müködését az államnak felügyelnie kell.

A gazdasági fejlődéselméletek alapelveit Szakolczai (1990) az alábbiakban foglalja össze. Szerinte azok alapvető tétele az, hogy korunk fö problémái gazdasági természetüek. Ha az elmaradottság és a szegénység megszủnne, a többi társadalmi kérdés is szinte automatikusan megoldódna. A szegénység és elmaradottság csökkentése a termelés növelésével érhetö el - folytatódik a magyarázat. A gazdaság 
Farkas Tibor : Vidékfejlesztés a fejlődéselméletek és a fejlesztési koncepciók tükrében

Tér és Társadalom 16. évf. 2002/1. 41-57. p.

teljesítöképességének valamint a lakosság jólétének és életszínvonalának mérésére legmegfelelöbb mutató a GDP, tehát a GDP növelése nemzeti összcél. A bírált elméletek képviselöi között egyetértés volt abban is, hogy a gazdasági növekedés elősegítése érdekében tőkefelhalmozásra, az eszközök megfelelő hasznosítására és a termelékenység növelésére van szükség. Az újabb nézetekben a munkaerő képzettsége és képzése játszik fontos szerepet. A fejlődéselmélet „emberi tőkét” előtérbe helyező változatai nem kérdőjelezik meg a korábbi elméleteket. Hozzájárulnak a gazdasági és a nem gazdasági kérdések korábbi megkülönböztetésének elmosásához. Mivel a munkafegyelem, a termelékenység és a vállalkozóképesség nagyrészt intézményes és kulturális szempontok által vezéreltnek tủnt, hozzájárulhatott a külső manipuláció hatékonyságához.

A fejlödést az különbözteti meg a növekedéstöl, hogy a folyamatot nemcsak mennyiségi, hanem minőségi változások is jellemzik. Pusztán valaminek a növekedését nem lehet feltétlenül fejlődésnek nevezni. Nemes Nagy (1998) álláspontjával egyetértünk, miszerint fejlődésről akkor beszélünk, amikor a változáshoz értéktartalom is párosul. A növekedéstöl az különbözteti meg, hogy míg a növekedésben a mértékek, addig a fejlödésben az értékek változnak.

A növekedés bizonyos eseteit Elkins (idézi Korten 1996) szerint csak akkor tarthatjuk egyáltalán pozitívnak, ha a növekedés eredendően értékes és hasznos javak és szolgáltatások termelésével jött létre, ha kimutatható, hogy ezeket a javakat és szolgáltatásokat széles körben igénybe tudják venni, valamint bizonyítható, hogy ezek az elönyök meghaladják a növekedési folyamatnak a társadalom más részeire gyakorolt káros hatásait.

Korten (1996) több olyan folyamatot mutat be könyvében, amelyekben a fejlödés ténye megkérdőjelezhető. A fejlődő, alacsony jövedelemmel rendelkező országokban például a gyors gazdasági növekedés modern repülőtereket, televíziót, gyorsforgalmi utakat, bonyolult elektronikus cikkeket és márkás divatcikkeket árusító, légkondicionált bevásárlóközpontokat hoz létre. Ezeket azonban a társadalomnak csak egy szük rétege tudja igénybe venni, a többség életkörülményei ritkán javulnak, így nem beszélhetünk fejlödésről. A fejlódés megítélésének szubjektív voltát Hoggart és Buller (1994) is kiemelik. Tanulmányukban Maslow szukséglethierarchiáját alkalmazták annak meghatározására, hogy az embercsoportok hogyan érzékelik és értékelik helyzetüket, fejlettségüket. Abraham Maslow amerikai pszichológus az emberi motivációnak hatszintủ hierarchiáját ${ }^{3}$ alkotta meg. Azt állította, hogy az emberi szükségleteket relatív fontosságuk alapján kategorizálni lehet. Amíg az alsóbb szintủ (alapvetőbb) szükségleteik kielégítése nem következik be, nem is érzékelik a magasabb szintủ szükségleteiket, nem törekszenek azok kielégítésére. Az amerikai szerzópáros szerint a szuikségletek ilyen hierarchiája alapján értékelhetö, hogy valamilyen település vagy embercsoport milyen szintü fejlesztést érez aktuálisan sajátjának, mit fogad el saját szükségleteit szolgáló fejlesztésnek. Az elméletet azonban kritikusan (is) kell szemlélnünk, hiszen maga a hierarchia is kultúrafüggő, és a különböző kis közösségeken belül is többféle értékrend létezhet. 
Farkas Tibor : Vidékfejlesztés a fejlődéselméletek és a fejlesztési koncepciók tükrében Tér és Társadalom 16. évf. 2002/1. 41-57. p.

TÉT XVI. évf. 2002 e 1

Vidékfejlesztés a fejlödéselméletek és a ...

45

\section{Az endogén és a regionális fejlödés}

A fejlödést „térbeli szemüvegen” keresztül is vizsgálhatjuk, ugyanis a gazdasági és a társadalmi fejlődésnek térbeli megjelenési formái is vannak. „Amikor a fejlödés fogalmát a térbeli vagy területi jelzövel bővítjük, tulajdonképpen csak azt jelezzük, hogy a térbeliséget nem a fejlődési folyamat mindig jelen lévő elemeként értelmezzük, hanem kiemelt vizsgálati szempontként kezeljük." (Nemes Nagy 1998)

A területi vagy regionális fejlödés szükebb fogalom, ám mégis gyakrabban használjuk, mint a térbeli fejlődést. Lackó (1987) szerint a területi fejlödés magában foglalja az ország egészére, különböző részeire és az egyes településekre jellemzö változásokat, a természeti erőforrások, a népesség, a termelés, az infrastruktúra és az intézmények területi eloszlási és változási viszonyait valamint a közöttük meglévő kapcsolatokat. Meghatározásában az értékek változása nem jelenik meg, de jól kiemeli a fejlődés gazdasági, társadalmi és környezeti összetevőit. Faragó (1994) szerint a területi fejlődés belső strukturális változásokat jelent, melyek eredményeként az egyén és a helyi társadalom számára a lehetőségek bövülnek, azaz több lehetöség (szolgáltatás) közül lehet választani, ill. ugyanaz a lehetőség szélesebb rétegek számára válik elérhetővé.

A regionális fejlődés esetében is az értékek változásán van a hangsúly. Enyedi (1996) regionális fejlődésen az életkörülmények és az életminöség javulását úgy érti, hogy közben a termékfogyasztás mennyiségi növekedése helyett egy egészségesebb és vonzóbb környezetben jó minőségủ és változatos termékek, szolgáltatások, szabadidős és kulturális tevékenységek fogyasztása történik.

Ha a fejlődés helyi vagy belső erőforrásokra alapozva történik, akkor endogén fejlődésről beszélünk. A belső erőforrások közé a helyi termelés és fogyasztás sajátosságai, a humán eröforrások állapota, a helyi tudás, a környezet állapota, a ,hely szelleme" stb. tartoznak. Az endogén fejlődés újjáélesztheti azokat az erőforrásokat, amelyeket egyébként elhanyagoltak, vagy az általános fejlesztési elképzelések figyelmen kívül hagytak. Long és van der Ploeg (idézi Szakál 1998) az endogén fejlődés lényegét így foglalja össze: „A fejlődés endogén mintái főleg, ha nem is kizárólagosan a helyileg rendelkezésre álló erőforrásokra épülnek, mint amilyenek a helyi technológia, a helyi munkaerő, helyi tudás (szakértelem), a termelés és fogyasztás összekapcsolásának helyi megoldásai stb. Ennél fogva az endogén fejlődés újjaélesztheti és dinamizálhatja azokat a helyi erőforrásokat, amelyek egyébként valószínüleg kihasználatlanok lennének. Másodsorban az endogén fejlődés mint egy „önközpontú” növekedési folyamat jelenik meg, amelyben az ilyen típusú fejlödés által generált összes értéket helyben fektetik be."

$\mathrm{Az}$ endogén fejlödésben ma már nem csak az alulról jövő (bottom up), hanem a felülről vezérelt (top down) megközelítések is helyt kapnak, amennyiben az állami funkciók és jogok kisebb területi egységekre történö átruházása megtörténik (Ray 1999). Mindkét megközelítés elfogadja, hogy sikeresebb a fejlesztő tevékenység, ha a helyi erőforrásokból indul ki, és a helyi közösség részt vesz benne (participáció). 
Szakál (1998) szerint az endogén típusú fejlödés ugyanúgy felhasználja a külső technológiai és piaci fejlesztéseket, mint az exogén, de: az adaptáció gyorsabb, nem egyszerü átvétel történik, hanem aktívan átalakítva és átértékelve építi be azokat, az ökológiai kihívásokra érzékenyebb, és a tranzakciós költség kisebb. Az endogén regionális fejlődés kapcsán Stöhr (1986 - idézi Rechnitzer 1994, 153) kifejti, hogy a regionális potenciálok összekapcsolódhatnak, közöttük szinergia-hatás léphet fel. A különbözö endogén források egymásra találása, valamint az exogén technikai és szervezeti innovációk dinamikus kölcsönhatása a korábbitól lényegesen eltérö regionális viszonyokat teremthet, további innovációk kialakulását és megtelepedését gerjesztheti, elösegítheti a régió gazdasági fejlődését. Az 1. ábra az endogén regionális fejlődés céljainak összetettségét mutatja be. A gazdaságiak csak az egyik célcsoportot képezik a négy alapvetö közül. Mellettük ugyanilyen fontos szerepet kapnak a társadalmi-kulturális, ökológiai vagy a politikai célok is.

\section{1. ÁBRA \\ Az endogén regionális fejlödés céljai és a közöttük lévö kapcsolatok \\ (The Aims of the Endogenous Regional Development and the Relationships between Them)}

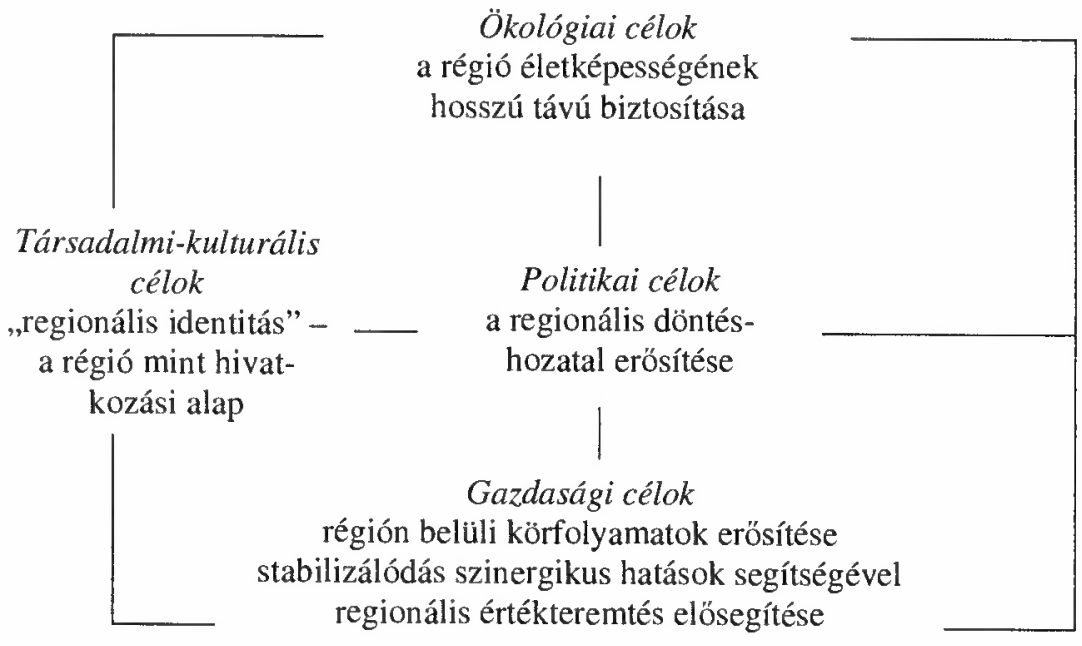

Forrás: VER-Niedersachsen 1990 (1991).

A fejlődés fogalmához szorosan kapcsolódik a fenntartható fejlődés paradigmája. Megjelenése széles körü vitát váltott ki az egész világon. Általában az a fejlődés tekinthető fenntarthatónak, amelyben a jelen generáció szükségleteinek kielégítése nem korlátozza a jövőbeni generációk szükségleteinek kielégítését. Más megfogalmazások is léteznek, mindenesetre csak azt fogadhatjuk el fenntarthatónak, ami gazdasági, társadalmi és környezeti szempontból is egyaránt fenntarthatónak bizonyul. Enyedi (1996) szerint a fenntartható regionális fejlődés legfontosabb célja az életminőség javítása. A növekedés-orientált paradigma szerinte csak akkor váltható 
Farkas Tibor : Vidékfejlesztés a fejlődéselméletek és a fejlesztési koncepciók tükrében Tér és Társadalom 16. évf. 2002/1. 41-57. p.

fel, ha a termékek fogyasztása helyett a szolgáltatások fogyasztása kerül elötérbe. Ha a regionális politikában érvényesülnének a fenntartható fejlődés elemei, akkor decentralizált fejlődés következne be. A népesség régiók közötti mozgása csökkenne, a helyi fejlesztések fontossága megnövekedne az országossal szemben. Magyarországon sok érdek füződik a korábbi, növekedés-orientált gazdasági modell folytatásához. A fenntartható fejlödés egyes részelemeinek az átvétele is fordulatot jelentene a társadalom és a környezet eddig kialakult viszonyában.

\section{A vidékfejlesztés a fejlesztési koncepciók tükrében}

A helyi fejlesztések közé sorolható a vidékfejlesztés is. Ez azonban nem csak egyszerüen kistérségek fejlesztését jelenti, annál összetettebb és bővebb fogalom. Jelen dolgozat egyik legnehezebb feladata éppen a vidékfejlesztés fogalmának a meghatározása. Különösen nehéz a vidék- és a területfejlesztés elhatárolása, hiszen mindkettő a spontán piaci folyamatok kiigazítására törekszik. Méginkább nehezíti a kérdést, hogy a területfejlesztés fogalomrendszere is viszonylag új, és az is éppen úgy küzd elismertetéséért, mint a vidékfejlesztés.

\section{A vidékfejlesztés és a területfejlesztés viszonya}

Az egyik probléma az, hogy a fogalmak definiálásához használt terminológiát sem használja mindenki egyértelmüen. Összemosódnak a terulet, a kistérség, a térség és a régió fogalmai is. Korábban a térség kifejezést kistérség és régió értelemben is egyaránt használták, a „régió” viszont a kialakult/kialakított tényleges régióknál kisebb vagy nagyobb területet is jelenthetett. Az országos területfejlesztési koncepció is rendkívül pontatlan a fogalmak használatában. Amikor pl. térségröl beszél, kistérségre gondol. Így azon sem lehet csodálkozni, ha a regionális fejlesztés és a területfejlesztés, a településfejlesztés és területfejlesztés, vagy a vidékfejlesztés és a területfejlesztés közé is egyenlőségjel kerül.

A területfejlesztés esetében Faragó (1994) meghatározására támaszkodhatunk. Eszerint a területfejlesztés a térhasználat tudatos irányítását jelenti. Az irányítási rendszerekhez hasonlóan területpolitikai, szabályozási, szervezeti/intézményi és eszközöket tartalmazó alrendszerei vannak. Jelen esetben nem térünk ki az egyes alrendszerek elemzésére. Egyedül a szervezeti és intézményi struktúra kapcsán jegyezzuik meg, hogy az követi a területi szinteket, azaz az országos szinttől egészen a települések szintjéig van érvényessége.

A vidékfejlesztésen általában a vidéken élö emberek életminöségének javítását értjük. Olyan összetett folyamatról van szó, melynek a gazdasági, társadalmi, szociális és környezeti hatásai is fontosak. Saját értelmezésünk szerint a beavatkozások a helyi emberek részvételével történnek, a helyben élők érdekében.

A vidékfejlesztés a hátrányos helyzetben lévő közösségek fejlesztésének tapasztalataiból alakult ki. Chambers (1983) könyvében hosszasan sorolja azokat a hibákat, Amelyeket a fejlesztésekben részt vevő munkatársak és a helyi döntéshozók elkö- 
vethetnek. Az ő definíciójában a vidékfejlesztés olyan stratégia, amely a hátrányos helyzetü emberek és gyermekeik számára lehetővé teszi, hogy a számukra kívánatos és szükséges erőforrások nagyobb részéhez jussanak hozzá. Ide tartozik a szegények felkarolása is, amikor elősegíti, hogy a vidéki területeken megélhetésük biztosítva legyen, és a fejlesztési eredményekből nagyobb mértékben részesüljenek. Ehhez a réteghez hozzátartoznak a kistermelök, a bérlök és földnélküliek is.

Kulcsár (1998) vidékfejlesztés-fogalmában az emberközpontúságot emeli ki. Ezen túl megállapítja, hogy a vidékfejlesztés kistérségi irányultságú, komplex társadalmi, gazdasági, kulturális programokon keresztül, a helyben élök aktív részvételével valósul meg. Madarász (1998) komplexitáson a gazdaság, a társadalom és a környezet egységére épülő szemléletet ért. Értelmezi a vidékfejlesztés és a politika kapcsolatát is, miszerint minden fejlesztés az emberi életkörülményekbe való beavatkozást jelent, az emberi létviszonyok megváltoztatását hozza magával, ezért a fejlesztés mindig politikai döntés eredménye, és mindig van politikai tartalma. Ha az érintett közösség nem értékeli fejlödésként a beavatkozást, vagy azt éppen a fejlődés ellentétének fogja fel, ezzel megakadályozhatja a fejlesztési elképzelés megvalósulását, vagy esetleges megvalósítása után nem tesz eröfeszítéseket a fenntartására. Copp (idézi Hoggart-Buller 1994) így ír erröl: „Javaslom, tekintsük vidékfejlesztésnek azt a folyamatot, amelynek keretében kollektív eröfeszítések történnek a városi területeken kívül élö emberek jólétének és önmegvalósításának jobbítása érdekében. Más szavakkal: hiszem, hogy a vidékfejlesztés végső célja az ember. Nem az infrastruktúra, nem a gyárak, nem a jobb oktatás, a jobb épületek vagy a jobb közösségek. Ezek mind eszközök; ha érintetlenül hagyják az emberek lelkét, mind csak por és füst lesznek."

A vidékfejlesztés egyben új alternatív fejlesztési paradigma is. Alkalmas arra, hogy felváltsa a modernizációs paradigmát. Ploeg (2000) több jellegzetességet is kiemel az alábbiakban. Az új paradigma kialakulásához a vidék megváltozott funkciói járulnak hozzá. A mezőgazdaság szerepe ma nem korlátozódik a városi népesség olcsó élelmiszerrel való ellátására. Az új európai mezőgazdaság elkezdett „,nem importálható" közjavakat termelni, mint pl. szép tájkép vagy természeti értékek. Tehát a vidékfejlesztés a mezőgazdaság számára is új fejlődési kihívást jelent. Az említett szerző kiemeli a szinergiákat, azaz azokat az újfajta kapcsolatokat, amelyek a farmok között ill. a farmok és más szereplök között jönnek létre. Igen fontosak a helyi és a regionális környezeti rendszerek között létrejövő szinergiák. Többek között leszögezi, hogy a vidékfejlesztés természetéhez hozzátartozik, hogy több területi szinten van érvényessége, több szereplö vesz részt benne, és többféle (gazdasági) tevékenység végzése is beletartozik.

Noha a vidékfejlesztés és a területfejlesztés meghatározásaiban különböző célokról és hangsúlyokról van szó, a két tevékenység viszonyát sokan sokféleképpen itélik meg. Kulcsár (1998) szerint alapvetően három felfogásról van szó:

1) a vidékfejlesztés a területfejlesztésnek alárendelt tevékenység,

2) a vidékfejlesztés és a területfejlesztés között nincs értelmezhető viszony, 
Farkas Tibor : Vidékfejlesztés a fejlődéselméletek és a fejlesztési koncepciók tükrében Tér és Társadalom 16. évf. 2002/1. 41-57. p.

3) a vidékfejlesztés és a területfejlesztés között sajátos mellérendelt viszony áll fenn.

A területfejlesztés és a vidékfejlesztés kapcsolatában az első felfogást az a vélemény képviseli, amelyik szerint a vidékfejlesztés a területfejlesztés integráns része, $S$ a vidékfejlesztés elkülönült kezelése csak indokolt esetben és ideiglenesen engedhető meg (Sïli-Zakar 1998). Ugyanebben a rendszerben a területfejlesztés alá tartozik a városfejlesztés és a regionális fejlesztés is. (A regionális fejlesztésen a szerzö a város-falu kapcsolatra épülő térségfejlesztést, a kistérségek, megyék, régiók fejlesztését érti.) A vidékfejlesztés és a területfejlesztés esetében nem fogadjuk el, hogy az elöbbi az utóbbinak integráns része lenne, és a vidékfejlesztés megkülönböztetése csak ideiglenesen lenne megengedhetö. Véleményünk szerint a két politika és fejlesztési tevékenység között átfedés van. Ez az átfedés a kistérségek fejlesztése. Ezen a területi szinten mindkét fejlesztési tevékenységnek van létjogosultsága, de amíg a vidékfejlesztés számára ez a szint a legfontosabb, addig a területfejlesztés esetében ez csak az egyik beavatkozási szint (2. ábra).

\section{2. ÁBRA}

A kistérségek a fejlesztési tevékenységek metszetében

(Small Regions in the Segment of Development Activities)

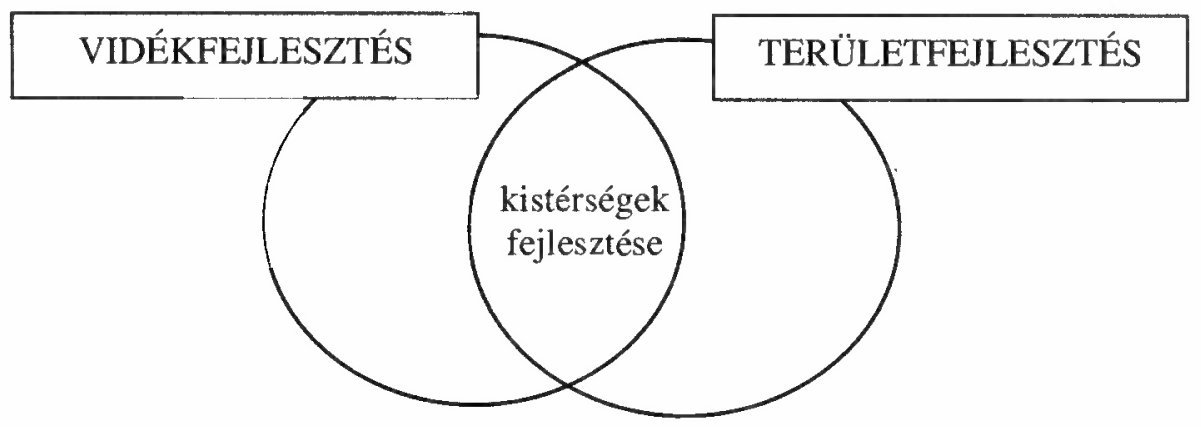

Forrás: Saját szerkesztés.

A vidékfejlesztéssel foglalkozó szakirodalom azonban általában mellérendelt kapcsolatot ismer el a területfejlesztés és a vidékfejlesztés között. G. Fekete (1998) szerint a vidékfejlesztés - amely a vidéki térségekben végbemenő változások alakulásába történő tudatos beavatkozásként értelmezhetö - különbözik a területfejlesztéstöl, mert kimondottan a vidéki érdekeket helyezi előtérbe. A szerző a következő különbségeket látja a vidék- és a területfejlesztés között:

- A centrumok és vidékeik fejlődése nem választható szét, de fejlesztésük másmás technikát igényel.

- A vidékfejlesztésben a természeti környezetnek, a földhasználatnak, az életkörülmények javításának és a centrumokban elérhető szolgáltatásokhoz való hozzáférésnek jut kitüntetett szerep, a fö szerepet a kisebb közösségek, civil 
Farkas Tibor : Vidékfejlesztés a fejlődéselméletek és a fejlesztési koncepciók tükrében

Tér és Társadalom 16. évf. 2002/1. 41-57. p.

szervezetek játsszák, és az érdekek egyeztetése közvetlen fórumokon, ill. informális csatornákon történik.

- A régiók fejlesztésénél a fö hangsúly a globalizált világgazdasághoz és a magasabbrendú centrumokhoz való kapcsolódáson, valamint a vidék eröforrásainak minél hatékonyabb bevonásán van. A területfejlesztésben meghatározó szerepet vállalnak a nagyobb szervezetek, és az érdekek egyeztetése politikai síkon történik.

Szakál (1998) szerint is létezik sajátosságaiban, célkitüzéseiben és módszereiben önálló vidékfejlesztési probléma és politika, amely nem azonos sem a területi, sem a regionális problémával vagy politikával. A vidékfejlesztés szoros kapcsolatban van ez utóbbiakkal, ezekkel összehangoltan lehet csak sikeres, mégsem kezelhetö azok részeként, nem oldható meg azoknak alárendelten.

\section{A vidékfejlesztés és az agrárfejlesztés viszonya}

Ugyancsak érzékeny terület a vidékfejlesztés és a mezőgazdaság viszonya. Sok szerzőnél a mezőgazdaság fejlesztése egyet jelent a vidékfejlesztéssel. ${ }^{4}$ A mezőgazdaság és a vidékfejlesztés kapcsolatára sem igaz azonban, hogy egyik a másik részhalmaza lenne (Kovács 1998; Kulcsár 1998; Szakál 1998). Hasonló véleményen van Dorgai (2000) is. Miközben figyelmeztet arra, hogy az agrárgazdaságnak a vidéki területek fejlödésében játszott jelenlegi és jövőbeni szerepét nem lehet elvitatni, nem ért egyet azokkal, akik azt mondják, hogy ha a mezőgazdaság problémáit megoldottuk, akkor a vidék problémái is rendeződnek. Másképpen megfogalmazva Kulcsár (1998) szerint: „A vidékfejlesztés számára a mezögazdaság tehát az egyik lehetséges és fontos aktivitási terület, ahol a kifejtett tevékenység az adott terület, kistérség adottságaitól, sajátosságaitól, az ott élő emberek gazdasági, társadalmi, kulturális helyzetétöl függ, s nem kötődhet egy termék- vagy szektorközpontú mezőgazdasági elképzeléshez."

Buday-Sántha (2001) szerint sem azonos az agrárpolitika a vidékpolitikával, noha jelentős mértékben átfedik egymást. A területfejlesztés, a vidékpolitika és az agrárpolitika szerint egymástól nem elkülöníthetőek, ,.,. ezek a rendszerek szimbiózisszerüen együtt élök, egyenrangúan és nem alá-, ill. fölérendeltségi viszonyban." (Dorgai 2000, 64) Fehér (1998) sem ért egyet a területfejlesztés és a vidékfejlesztés viszonyának ,rész-egész" relációval történő jellemzésével. A vidékfejlesztési politikát szerinte sem lehet egyetlen tárcához rendelni. A szerzó szerint a vidékfejlesztési politikának több kapcsolódási pontja lehet a különbözö politikákkal, de az egyes ágazatokon belül nincs minden elemnek kapcsolata a vidékfejlesztéssel. Az agrárpolitikában ilyen a termeléspolitika, a piacpolitika vagy a müszaki fejlesztési politika.

A 3. ábra hasonló felfogásban készült. A finn szerző ugyancsak a vidékpolitika, a területi és az ágazati politikák kapcsolatát mutatja be. Az egyes politikák között átfedések vannak. A különböző ágazati politikák eltérő mértékben vesznek részt a 
Farkas Tibor : Vidékfejlesztés a fejlödéselméletek és a fejlesztési koncepciók tükrében Tér és Társadalom 16. évf. 2002/1. 41-57. p.

TÉT XVI. évf. 2002 - 1 Vidékfejlesztés a fejlödéselméletek és a ... 51

másik két politika formálásában. Az ágazati politikák közül ki kell emelni a mezögazdasági politikát, hiszen az - miként egyes szerzők említik - a vidékfejlesztés gerince.

\section{3. ÁBRA}

A vidékpolitika a regionális politika és az ágazati politikák közötti kapcsolat (Relationships between Rural Policy, Regional Policy and Sectoral Policies)

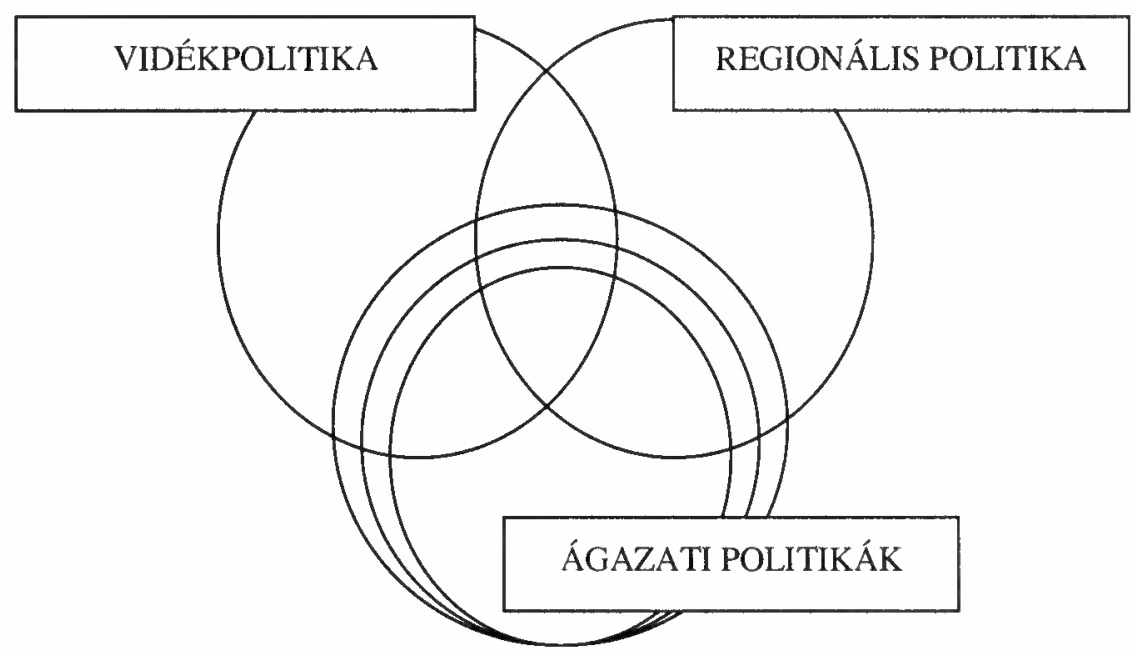

Forrás: Malinen 1996, 39. o.

A vitát jelen dolgozat keretein belül sem lehet lezárni. Saját véleményünk összegzéseként talán annyit lehetne hozzáfüzni, hogy a vidékfejlesztés és a vidékpolitika alkalmas arra, hogy önálló problématerületként kezeljük. Szoros kapcsolatban áll más strukturális és az ágazati politikákkal, ám olyan jellegzetességei vannak, amelyek a többitől eltérö módszereket és megközelítéseket igényelnek. A megközelítések között fontos szerepet kap a kistérségi megközelítés, az emberközpontúság, az endogén eröforrásokra történő támaszkodás, az alulról jövő kezdeményezések hangsúlyos figyelembevétele, a szubszidiaritás. Utolsóként ugyan, de nem kevésbé fontos az a tény sem, hogy közösségi munkáról is szó van. A fejlesztések irányítója, végrehajtója és eredménye is a magasabb életszínvonalon élő, jobb és emberibb helyi közösség.

\section{További megközelitések és koncepciók}

A vidékfejlesztés esetében - ahogyan az elöző alfejezetben említettük - hangsúlyosabban jelenik meg a közösség. A helyi társadalom, a civil szervezetek, a vállalkozók bevonása nélkül a kistérségi programok nehezen valósíthatók meg. Valahol meg kell húzni azt a kört, amelyen belül az említett szereplők könnyen elérhetők, amelyen belül elegendő belső erőforrás áll rendelkezésre. Olyan emberekre van 
Farkas Tibor : Vidékfejlesztés a fejlödéselméletek és a fejlesztési koncepciók tükrében

Tér és Társadalom 16. évf. 2002/1. 41-57. p.

szükség, akik jól ismerik egymást, megbíznak egymásban, és ezáltal a tranzakciós költségek is csökkennek. Magyarországi viszonyok között ez a terület nagyjából egy kistérségnyi.

Talán közhely, hogy az emberek általában kötódnek szülöhelyükhöz, lakóhelyükhöz. Azt a tájat, azokat az embereket ismerik, azokkal tudnak azonosulni. Enyedi $(2001,20)$ így fogalmaz: „Az emberek téridentitása - egy adott térséggel való azonosulása - a településükkel, a közvetlen élettapasztalatokat nyújtó kistájjal a legerösebb. Nemigen vallja senki, hogy ő dél-dunántúli, de azt igen, hogy sellyei vagy göcseji. S amikor valaki göcsejinek vallja magát, ez nem egyszerü helymeghatározás, hanem azonosulás a sajátos természeti tájjal, a táj sok generáció által megélt történelmével, faluja/városa településképével, szokásaival és értékrendjével, a helyi társadalomban elfoglalt helyével, a helyi kultúrával. Mindez független az éppen érvényes közigazgatási vagy statisztikai számbavételi egységektöl, a megélt tér élménye nem reflektál a tér mesterséges felosztásaira."

Benko (1997) is a helyi közösségek nehezen kimutatható jellegzetességeire hívja fel a figyelmet, amikor „, Harmadik Itália csodájának” körzeteiről beszél. A sikerben nagy része volt a szabályozásban megjelenő ,atmoszférának": a civil társadalom családjai valamint a vállalkozók és alkalmazottak közötti bizalomnak, továbbá a helyi közösségek szerepének. A szükségszerüen elég „,kisméretü” közösség a Tönnies szerinti „Gemeinschaft"-nak felel meg.

A társadalmi-gazdasági életben az ügyletek jelentős része nem formális szerződéseken alapszik. Fontosabbak a közvetlen kapcsolatok, a személyes ismeretségek, a kölcsönös bizalom. Az ilyen kapcsolatokra épülö szerződések azért kerülnek az érdeklődés középpontjába, mert segítségükkel a tranzakciós költségek csökkentése lehetővé válik. Ez utóbbi Szakál (1998) megállapítása szerint csak az említett „közösségi típusú" szervezetekben mehet végbe. Ilyen szervezetek lehetnek a család, a szövetkezet, a családi vállalkozás és a legkülönfélébb civil szervezödések is. Ezért végül leszögezi, hogy a vidékfejlesztés szempontjából többek között a helyhez valóban kötődő, önazonossággal rendelkező vidéki közösségeknek van meghatározó jelentősége. A vidékfejlesztés tehát fóképpen ilyen okok miatt választja a kistérségi szintet mint legfontosabb múködési területet.

A vidékfejlesztés újszerú megközelítését az 1. táblázatban is megfigyelhetjük. A környezet a vidékfejlesztés számára nem egyszerủen különféle nyersanyagokat jelent, hanem szerves egészként kezelendő. Hasonlóan az előzőhöz az emberi erőforrás nem egyszerüen munkaerö, hanem képességekkel rendelkezö helyi társadalom.

A felhasználható erőforrások érkezhetnek kívülről, ill. létezhetnek az adott térségen belül is. Endogén fejlesztésrỏl akkor beszélünk, amikor a fejlesztés a helyi eröforrásokra támaszkodik. Tágabb értelemben ez azt jelenti, hogy a fejlesztési elképzeléseket helyben határozzák meg, a folyamatot helyben ellenörzik, a fejlesztés haszna megmarad a helyi közösségen belül, s mindezek a helyi értékek szem elött tartása mellett mennek végbe (idézi Kulcsár-Madarász 2000). 
Farkas Tibor : Vidékfejlesztés a fejlödéselméletek és a fejlesztési koncepciók tükrében Tér és Társadalom 16. évf. 2002/1. 41-57. p.

TÉT XVI. évf. 2002 — 1 Vidékfejlesztés a fejlödéselméletek és a ... 53

\section{TÁBLÁZAT}

A vidékfejlesztés hagyományos és modern eröforrásai (Traditional and Modern Resources of Rural Development)

\begin{tabular}{|c|c|c|}
\hline \multirow{2}{*}{ ERÖFORRÁS } & \multicolumn{2}{|c|}{ ÉRTELMEZÉS } \\
\hline & HAGYOMÁNYOS & MODERN \\
\hline Természeti & $\begin{array}{c}\text { eröforrások elkülönített fel- } \\
\text { használása }\end{array}$ & környezet mint rendszer \\
\hline Emberi & munkaerő & $\begin{array}{l}\text { helyi társadalom (képességekkel } \\
\text { és kreativitással rendelkezik) }\end{array}$ \\
\hline Infrastrukturális & $\begin{array}{l}\text { lokációs (letelepedési) } \\
\text { tényezỏ }\end{array}$ & $\begin{array}{l}\text { rendszerként segíti a helyi vál- } \\
\text { lalkozási környezet kialakítását }\end{array}$ \\
\hline Pénzügyi & $\begin{array}{l}\text { közvetlen felhasználás } \\
\text { (fejlesztési tényezó) }\end{array}$ & $\begin{array}{c}\text { közvetett felhasználás } \\
\text { (a helyi gazdasági-társadalmi } \\
\text { területi rendszer kialakulását } \\
\text { elósegíti) }\end{array}$ \\
\hline
\end{tabular}

Forrás: Parysek alapján (idézi Brown-Bandlerova 2000, 98).

Az endogén fejlődésen alapuló fejlesztéseknél azonban nem lehet mellözni a külső adottságokat sem. A helyi adottságokba történö bezárkózás azt is meggátolhatja, hogy a külsỏ adottságokat befolyásolni tudjuk. Ugyanakkor a csak a kívülállók akaratán múló (exogén) fejlődés/fejlesztés függést hozhat létre (Hoggart-Buller 1994). A külső segítség előmozdíthatja a fejlesztést, de a segítség elmaradásakor a közösségek képtelenekké válhatnak a fejlődés fenntartására, s ebben az esetben csak a létfeltételek rövid távú javulásáról beszélhetünk. Cernea (1994) is hasonlóan vélekedik: a fejlődés különböző oldalainak, összetevőinek csak az együttes fejlesztése vezethet eredményre. Például, amikor a külső, pénzügyi segítségnyújtás válik a legjelentősebbé egy bizonyos térségben, akkor az a kialakult társadalmi szerveződések és intézmények mintázatán valószínüleg nem fog változtatni, azaz nem történik változás a fejlődés nem-pénzügyi szektoraiban, s így összehangolhatatlanná válik a projekt.

$\mathrm{Az}$ endogenitás mellett gyakran emlegetik a szubszidiaritás elvét. A szubszidiaritás gondolata messzire vezethető vissza. Míg a második világháború elött inkább csak társadalom-filozófiai kategória volt, utána jogi gondolatként is szerepet kapott. Az Európai Unióban használata meglehetősen vitatott, mivel kedvezőbb helyzetbe hozza a tagállamok jogalkotását az unióssal szemben (Kecskés 1998). A területpolitikában a szubszidiaritás jóval elfogadottabb kategória. Lényegében azt jelenti, hogy a problémákat azon a területi szinten kell megoldani, amelyeken azok felmeruiltek. Más szavakkal ez azt jelenti, hogy azt a feladatot, amelyet egy kisebb közösség meg tud oldani, nem szabad kivenni a kezéből, vagy egy magasabb társadalmi szerveződésre bízni. A szubszidiaritás alapelvének megfelelően felépülő társadalomban a társadalom szerveződése nem felülről lefelé, hanem alulról felfelé történik.

A vidéki kistérségek fejlesztésénél is a „top down” helyett inkább a „bottom up”, azaz alulról történő építkezés megközelítését alkalmazzák. A 2. táblázat nagyrészt 
Farkas Tibor : Vidékfejlesztés a fejlödéselméletek és a fejlesztési koncepciók tükrében

Tér és Társadalom 16. évf. 2002/1. 41-57. p.

összefoglalja az utóbbi bekezdésekben taglaltakat. A vezérlés két eltérö iránya mögött különböző fejlödésfogalmak, elméletek, fejlesztési célok, elképzelések és más célcsoportok állnak. G. Fekete (1998) szerint a vidékfejlesztés esetében - ahogyan azt az endogén és exogén erőforrások esetében is megemlítettük - nem lehet kizárólag az egyik vagy másik felfogásra támaszkodni. Noha a vidékfejlesztés esetében kitüntetett szerepe van a „bottom up” megközelítésnek, figyelembe kell venni, hogy nehezebben szervezhetö és követhetö, valamint idö- és munkaigényes is.

\section{TÁBLÁZAT}

A felülröl és az alulról vezérelt fejlesztés föbb elemeinek összehasonlítása (Comparison of Main Elements of Top-down and Bottom-up Development)

\begin{tabular}{|c|c|c|}
\hline & $\begin{array}{l}\text { Felülröl vezérelt (top down) } \\
\text { fejlesztés }\end{array}$ & $\begin{array}{l}\text { Alulról építkező (bottom up) } \\
\text { fejlesztés }\end{array}$ \\
\hline Fejlödésfogalom & $\begin{array}{l}\text { monolitikus fejlödésfelfogás, } \\
\text { mely mögött egységes érték- } \\
\text { rendszer és emberi boldog- } \\
\text { ság-fogalom áll }\end{array}$ & $\begin{array}{l}\text { közösségenként különböző és } \\
\text { változatos értékrendszerek }\end{array}$ \\
\hline Uralkodó elmélet & $\begin{array}{l}\text { neoklasszikus fejlődéselmé- } \\
\text { letek, növekedési pólus } \\
\text { elmélet }\end{array}$ & alternatív fejlődéselméletek \\
\hline Fejlesztési cél & gazdasági növekedés & $\begin{array}{l}\text { alapszükséglet kielégítése, } \\
\text { életminőség javítása }\end{array}$ \\
\hline $\begin{array}{l}\text { Fejlesztési célcso- } \\
\text { port, kedvezménye- } \\
\text { zettek }\end{array}$ & nagyvállalatok & $\begin{array}{l}\text { kis- és középvállalkozások } \\
\text { valamint a helyi közösségek }\end{array}$ \\
\hline Fejlesztés alanyai & $\begin{array}{l}\text { a központi akaratot megva- } \\
\text { lósító hivatalok }\end{array}$ & $\begin{array}{l}\text { a helyi emberek bevonásával } \\
\text { müködỏ közösségek }\end{array}$ \\
\hline $\begin{array}{l}\text { A fejlesztés erőfor- } \\
\text { rásainak ellenörzése }\end{array}$ & $\begin{array}{l}\text { helyi erőforrások ellenőrzése } \\
\text { kívüllröl }\end{array}$ & $\begin{array}{l}\text { helyi erőforrások ellenörzése } \\
\text { helyben }\end{array}$ \\
\hline Térbeni hálózatok & $\begin{array}{l}\text { vertikális, hierarchikus tér- } \\
\text { szerveződés }\end{array}$ & horizontális térszervezödés \\
\hline
\end{tabular}

Forrás: G. Fekete 1998, 81-82. oldalak alapján.

Az eddigiek alapján is kiderült, hogy a vidéki kistérségek fejlesztésénél a helyi közösségeknek fontos szerep jut, így a különböző megközelítések és koncepciók tárgyalásakor nem lehet megkerülni a közösségfejlesztést. Varga és Vercseg $(1998,20)$ a következóképpen határozzák meg az utóbbi fogalmat: „A közösségfejlesztés vagy közösségszervezés felfogásunkban elsősorban települések, térségek, szomszédságok közösségi kezdeményezö- és cselekvőképességének fejlesztését jelenti, amelyben kulcsszerepe van a polgároknak, közösségeiknek és azok hálózatainak, valamint a helyi szükségletek mértékében a közösségfejlesztóknek is, akiknek bátorító-ösztönző, informáló, kapcsolatszervező munkája életre segítheti vagy kiegészítheti, megerösítheti a meglévő közösségi erőforrásokat." A közösségfejlesz- 
Farkas Tibor : Vidékfejlesztés a fejlődéselméletek és a fejlesztési koncepciók tükrében

Tér és Társadalom 16. évf. 2002/1. 41-57. p.

tésen tulajdonképpen azt a munkát értjük, amit a közösség saját magán végez a különbözö fejlesztések végrehajtása és a közösség jövője érdekében. Így a közösségfejlesztö munka a vidékfejlesztéssel összefüggö, annak szerves részét képezö tevékenységnek fogható fel.

\section{Összefoglalás}

A fejlödéssel és a fejlesztéssel foglalkozó dolgozatunkban terjedelemi okok miatt sem fejthettünk ki minden egyes érintett témakört. Így a fenntartható fejlődés és fejlesztés vizsgálata is megért volna egy külön vizsgálatot. Mindazonáltal a fejlödés, valamint a vele kapcsolatos fogalmak és koncepciók áttekintése azért volt fontos feladat, mert anélkül, hogy tudnánk, mit jelent a fejlödés, nem kezdhetünk semmilyen fejlesztési tevékenységbe. A vidékfejlesztés és a területfejlesztés kapcsán próbáltuk különválasztani a kétfajta tevékenységet, s az alá- és fölérendeltség helyett inkább arra helyeztük a hangsúlyt, hogy a kétfajta tevékenység között átfedés van. Ez az átfedés éppen a kistérségek szintjén figyelhető meg leginkább, hiszen mindkét tevékenységnek van létjogosultsága ezen a szinten. Bővebben foglalkoztunk azokkal az elképzelésekkel - ugyan itt sem a teljesség igényével -, amelyek a vidékfejlesztési gondolkodást és gyakorlatot formálják. Ezen koncepciók közé tartozik többek között a kistérségben/helyi közösségekben való gondolkodás, a szubszidiaritás, az endogenitás, a tranzakciós költségek csökkentése, az alulról felfelé való építkezés valamint a közösségfejlesztés. Az is látható azonban, hogy egyfajta közeledés is tapasztalható a vidékfejlesztés és a területfejlesztés között, mégpedig az egyes megközelítések alkalmazásával kapcsolatban. Foglalkoztunk a vidékfejlesztés és a mezőgazdaság fejlesztésének dichotómiájával is. Itt azt tapasztaltuk, hogy az agrárpolitika az a talán legfontosabb ágazati politika, amely hatással van a vidék fejlödésére, de ez a szerep nem kizárólagos. Csak a mezőgazdaság, ill. a mezőgazdaságból élök fejlesztésével nem tudnánk megoldani a vidék problémáit.

\section{Jegyzetek}

'A dolgozat a szerző Kistérségek a vidékfejlesztésben címủ doktori disszertációjának első két fejezete alapján készült.

${ }^{2}$ Gerhard Heilig szóbeli közlése nyomán, Gödöllö, 2002.

${ }^{3}$ A Maslow-féle hierarchia: 1) esztétikai szükségletek (pl. tájkép); 2) önmegvalósítás („Ami egy ember lehet, annak is kell lennie."); 3) kompetencia, presztízs, elismertség (szakmai hozzáértés, egyén saját értékei); 4) szociális szük ségletek (a valahová tartozás szulkséglete, pl. szeretet, barátság); 5) biztonságérzet (a létfenntartás biztonsága, pl. rendszeres jövedelem, nyugdíj); 6) fiziológiai szükségletek (az élet biológiai fenntartása, pl. alvás, étkezés, szex).

${ }^{4}$ Az Országos Területfejleszztési Koncepció (1997) pl. contradictio in adiectio, „mezögazdasági (rurális) vidékfejlesztés térségei"-röl ír. Az ehhez kapcsolódó fejlesztési elképzelések is föként mezögazdasági fejlesztések. 


\section{Irodalom}

Benko, G. (1997) A regionális fejlödés útjai: globálistól a lokálisig. - Tér és Társadalom. 2. 1-16. o.

Brown, D.-Bandlerova, A. (eds.) (2000) Rural Development in Central and Eastern Europe. Slovak Agricultural University in Nitra.

Buday-Sántha A. (2001) Agrárpolitika - Vidékpolitika (A magyar agrárgazdaság és az Európai Unió). Dialóg Campus Kiadó, Budapest-Pécs.

Cernea, M.M. (1994) A társadalomtudományi ismeretek a fejlesztési politikában és a projektekben. Madarász I. (szerk.) Szöveggyüjtemény a vidékfejlesztés szociologiája tantárgy tanulmányozásához. Gödöllö. 67-80. o.

Chambers, R. (1983) Rural Development: Putting the Last First. Longman Group UK Limited, Essex.

Dorgai L. (2000) Feladataink a vidékpolitika alkalmazásában. - Gazdálkodkis. 5. 63-68. o.

Enyedi Gy. (1996) Regionális folyamatok Magyarországon. Hilscher Rezső Szociálpolitikai Egyesület, Budapest.

Enyedi Gy. (2001) Tájak, régiók, települések Magyarországon. - Ezredforduló. 4. 19-23. o.

Faragó L. (1994) Adalékok a területfejlesztéssel kapcsolatos fogalmak vitájához. - Tér és Társadalom. 3-4. 23-39. o.

Fehér A. (1998) Mezögazdaság és vidékfejlesztés. - Gazdálkodás. 1. 72-79. o.

G. Fekete É. (1998) Bevezelés az alulról vezérelt (bottom up) vidékfejlesztés elméletébe és módszertanába. Kereskedelmi és Gazdasági Föiskola, Szolnok.

G. Fekete É.-Bodolai É. (1995) „Együtt! - De hogyan?” (Kistérségi szerveződések megjelenése a területfejlesztésben). MTA Regionális Kutatások Központja, Miskolc.

Hoggart, K.-Buller, H. (1994) Vidékfejlesztés. - Madarász I. (szerk.) Szöveggyüjtemény a Vidékfejlesztés szociológiája tantárgy tanulmányozásához. Gödöllö. 28-38. o.

Kecskés L. (1998) EK-jog és jogharmonizáció. Közgazdasági és Jogi Könyvkiadó, Budapest.

Korten, D.C. (1996) Tökés társaságok világuralma. Kapu, Budapest.

Kovács K. (1998) A vidék kutatása az MTA Regionális Kutatások Központjában. - A Falu. 4. 15-30, o.

Kulcsár L. (1998) Vidékfejlesztés és vidékpolitika Magyarországon, - A Falu. 2. 5-15. o.

Kulcsár L.-Madarász I. (2000) A vidékfejlesztésben érvényesülö érték- és orientációs szempontok. Kulcsár L. (szerk.) Vidékfejlesztés. (tankönyv - kézirat) Scolar Kiadó, Budapest.

Lackó L. (1987) A terilleti fejlödés egységes értelmezése. - Tér ês Társadalom. 1. 67-75. o.

Malinen, P. (1996) Changing Rural Policy in Finland. - Finnish Journal of Rural Research and Policy. English Supplement. 3. 35-52. o.

Nemes Nagy J. (1998) A tér a társadalomkutatásban. (Bevezetés a regionális tudományba). Ember Település Régió, Budapest.

Polányi K. (1997) A nagy átalakulás. Mészáros Gábor kiadása, Budapest.

Ray. Ch. (1999) Towards a Meta-Framework of Endegenous Development: Repertoires, Paths, Democracy and Rights. - Sociologia Ruralis. 4. 521-538. o.

Rechnitzer J. (szerk.) (1994) Fejezetek a regionális gazdaságtan tanulmányozásához. MTA Regionális Kutatások Központja, Györ-Pécs.

Struff, R. (1992) Wohnen, Arbeiten und Sozialhilfe. Regionale Lebensverhältnisse. Teil 1. Bonn.

Süli-Zakar I. (1998) Területfejlesztés-vidékpolitika. - A Falu. 3. 65-70. o.

Szakál F. (1998) A hazai vidékfejlesztés rendszerének EU-konform kialakítási lehetőségei. I. A vidékfejlesztés szervezési és ökonómiai problémái, a mezögazdasági és a vidékfejlesztési politikák összefüggései. GATE Környezet- és Tájgazdálkodási Intézet, Gödöllö.

Szakolczai Á. (1990) A fejlödés megkérdôjelezése - A gazdastagi fejlödés modern mítosza és valós alapjai. Akadémiai Kiadó, Budapest.

Varga A.T.-Vereseg I. (1998) Közösségfejlesztés. Magyar Müvelõdési Intézet, Budapest. 


\section{RURAL DEVELOPMENT IN SCOPE OF THE DEVELOPMENT THEORIES AND CONCEPTS}

\section{TIBOR FARKAS}

Recent paper deals with the theories and concepts of development. This is quite important issue, because there is a need to define the goals of different development activities. In case we couldn't suspect the change or the possible result caused our activity, is not allowed to start such kind of process. Rural development is a new phenomena in Hungary. Different scholars interpret rural development in different ways. This paper says that rural development not just structural or sectoral activity. There is an overlapping, because regional development activities effect small regions on the countryside and agricultural activity is strongly connected to rural life and economy, too. However rural development is a bottom up approaches unlike regional development. To improve the quality of life in rural areas is not enough only to develop or diversify agricultural activities, because rural development is a multi-actor and multi-facetted process. 